\title{
Strengths and Weaknesses of Human Resources in Regional Development Planning of Vojvodina Province
}

\author{
Djurdjev, $B^{*}$, Kicošev $S^{*}$, Vuksanović G. ${ }^{* *}$
}

Abstract Work on Regional development plan of Vojvodina province was an opportunity for the team members to articulate major strengths, weaknesses, opportunities and threats in an ex-post analysis and to depict them in a short and illustrative way in SWOT analysis. This paper presents major findings in the area of human resources.

Key words Vojvodina, Development planning, Strengths, Weaknesses, Opportunities, Threats

\footnotetext{
Branislav S. Djurdjev, Kicošev Saša, University of Novi Sad, Faculty of Natural Sciences, Department of Geography, Tourism and Hotel Managament, Trg Dositeja Obradovića 3, 21000 Novi Sad, Serbia and Montenegro

** Gordana Vuksanović, University of Novi Sad, Faculty of Philosophy, Department of Sociology, 21000 Novi Sad, Serbia and Montenegro
}

WOT (Strengths, Weaknesses, Opportunities and Threats) analysis is a handy scientific tool. It is devised to present results of an analysis in an easy and comprehensive way. This is just a way of presentation, not a scientific method.

SWOT analysis is a part of each regional development plan. In the sequence of development planning stages SWOT analysis comes after ex-post analysis. The mentioned two are the basis for extracting regional development goals and strategies and for the definition of final stage, e.g. priorities of development and outline of activities.

Most recent records on the population in Vojvodina enable us to follow its growth from 1828. It shows that the population in Vojvodina has been constantly growing and that it was significantly influenced only by six social events. The Serbian national movement (1848-1849), abolition of military border and two World Wars had only temporarily stopped the demographic growth in Vojvodina. Maximum result of this growth is 2,034,772 inhabitants from the 1981 census. This is followed by a serious depopulation and until 1991 the number of people living in this area was reduced for 20,883 people. Problem of negative natural growth continued during the last intercensal period (19912002), and a slight increase in number is due to the large intake of refugees in the period 1990-1996.

The data from the 1869 census are more reliable and they show that the population number has risen for 879,524 or more than three quarter from the number of the first census. In the past 133 years the average annual growth has been only 0.4 percent or 6613 new residents per year. If the population growth continued with the same pace it would double only after 163 years, that is in 2032.

Looking at the population growth by the individual intercensal periods, it is noticeable that the population of Vojvodina has had a growth of more than one percent per year only in two periods. In all other periods the growth rates were appreciably lower from the unit, and in the 1981-1991 inter- censal periods instead of the growth rate we can talk about the decrease rate, which means that there is no chance of doubling the population. If the below replacement level of fertility continues, current number of people will be halved in the far future.

The growth rate is low in all other parts of the modern world, as well. The average growth rate in Europe was only 0,2\% in the period between 1985-1990 (just as in Central Serbia in the period between 1981-1991). There was no European country at that time in which the growth rate was higher than one percent per year. In Germany and Hungary the growth rate was negative (just as in Vojvodina in the period between 1981-1991).

Demographic growth in Vojvodina has for long time been following the West-European trend in the demographic transition and fertility decline. That is why every effort to change the situation on the local level has been futile.

Lamentation over bad trends of demographic growth in Vojvodina in the second half of the twentieth century has no basis, since the average annual growth rate in this period is the same as the annual average rate for almost one and a half century. This means that, even the large number of people who immigrated after the War improved neither the conditions for biological reproduction nor did they significantly contribute to the mechanical growth of the number of inhabitants in Vojvodina. The postwar colonization only made up for the expelled Germans. Between the 1948 and 1991 census migration balance was negative due to large excess of people who emigrated in the first and last intercensal period. Thanks to the refugee movement in 1991-1996, census 2002 shows positive sign of overall net migration after WW2.

In the postwar period, there were a large number of both immigrations and emigrations in Vojvodina. It seems that this phenomenon has a deeper root, which indicates that this area has kept its transitive features today as well, just like in the old days, when large number of people was coming to and going from here. Regardless of the important role of the immigrants, population growth of only $22 \%$ or 373,132 people in period between 1948-1991 was the natural population growth. Census of 2002 demonstrates that the only source of the latest population increase was refugee intake.

\section{Natural increase}

Since the beginning of the twentieth century the natural population growth in Vojvodina has ranged from maximum $1,3 \%$ recorded in 1920 , to minimum $-1,8 \%$ in 1918. The natural population growth was higher than $1 \%$ only in seven more years 
in the first decade of the twentieth century and in six years between 1949 and 1955 (with the exception of 1951). Apart from the first four years of the First World War the natural population growth was negative in the Second World War and at the end of the twentieth century.

Until the end of the twentieth century wars were the cause of both maximum and minimum values of the natural population growth in Vojvodina. Therefore, what strikes the most is the fact that, starting from 1989, the annual number of the deceased has been exceeding the number of the newborn babies, and the difference between the figures is constantly increasing. According to previous results, in 1997, the rate of population growth fell to $-0,42$ percent per year. If this tendency continues and if there are no significant migrations in Vojvodina, the number of people will start reducing for one percent every year. This will result in halving the population in less than 70 years.

How did the demographic transition go in Vojvodina? In order to study that, we shall separate three periods in the demographic development of Vojvodina: the period before the First World War, the period between the two wars and period after the Second World War.

In the period between 1901-1914, the birthrate was above four percent for four years (maximum birthrate of 4.05 percent was recorded in 1905), and during the remaining years it was constantly above 3.5 percent (except for 1914 when it was 3.42). This level of birthrate is high even for the world's standards. Mortality was also very high. For four years it was more than 3 percent, and it was never below 2.7 percent. The maximum mortality in this period was in 1908 with 3.11 percent (the highest level of mortality in Vojvodina was recorded in 1918 when out of a thousand people 38.2 died).

In the period between 1919-1940 the birthrate was higher than 1 percent only in the first three postwar years (with the maximum of 3.88 in 1920), and then there was a plunge to 2.5 percent, which continued all the way to 1.87 percent in the years before the World War Two. Mortality decreased quickly from postwar 2.5 percent to 1.5 percent from before the war. The average of 2 percent was an extremely high mortality rate in Europe in that time. According to the UN data (United Nations, 1953), in 1930-31 the highest mortality rate in the provinces of around twenty European countries was recorded in Kosovo and Metohija and it was 2.36 percent. In Vojvodina, the average for these two years was 1.94 (in central Serbia it was 1.77), and only a year earlier it was 2.2 percent.

After the World War Two the birthrate was above 2.5 percent only in 1949 and 1950, and until 1955 it was above 2 percent. The birthrate, then, started to decrease slowly and, in the last years, it was nearly 1 percent per year. Net rate of reproduction has been below the unit from 1955, that is, below the level needed for the regeneration of the population. Until 1956, the mortality rate was constantly above 1 percent. However, in 1966, it decreased to 0.88 percent (minimum for the twentieth century), and then started to increase to today's 1.4 percent. These negative mortality conditions are best seen through the life expectancy. In $1995 / 96$, in Vojvodina, it was 68.3 years for men and 73.4 years for women. These figures were the lowest within Yugoslavia (the longest life expectancy is in Kosovo and Metohija, 72.7 for men and 77.7 years for women). In the period between 19851995 in the developed countries of the world, the average birthrate was 1.4 percent, whereas the mortality rate was 1 percent. This means that the modern birthrate in Vojvodina is below the average, and mortality is above the average (in Kosovo and Metohija, the mortality rate, in 1993, was only 0.39 percent).

Demographic transition of Vojvodina can be described with the following sentence: the early stage of demographic transition began at the beginning of the twentieth century, characterized by the decrease of, until that period, high fertility and stable high mortality. In the period between Wars, moderate fertility decreases quickly and in parallel with high mortality. And after the World War Two the decrease in birthrate continued a bit slower, though, and relatively high mortality for the late transitional stage began to increase. Vojvodina, is, therefore, characterized by high fertility before the demographic transition, lack of demographic explosion in the middle stage of transition, constant high mortality rate and, as a result of the above, slow and even negative natural population growth.

\section{Migrations}

Vojvodina has often changed rulers. Only in the last three centuries there were Turks, Austrians, Hungarians (partly Germans and Croats) and Serbs. All of them used to inhabit this area mostly with their own people. Frequent massive immigrations and occasional emigrations have had the crucial role in creation of the demographic frame, within which the population of Vojvodina lived and developed.

Since there are more reliable records for the period after the World War Two, on the basis of archives and census returns, using vital-statistics method for determining the migration balance, we are able to distinguish the following types of outer migrations in Vojvodina:

- Exodus of Germans in 1944-1948,

- Colonization in 1945-1948,

Return of colonists and emigration,

- Settling of agrarian population in 1954-1965
Economically motivated migrations with the stage of going abroad for temporary employment

Refugees1990-1996

\section{Refugees 1990-1996}

Among the large refugee destinations, Vojvodina stands out as a place where the share of refugees in the total number of people, is as twice as high, compared to other destinations.

However, if municipalities are taken as destinations this division is yet more uneven. From the total number of 209 municipalities in Yugoslavia, only in 17 of them there are more than ten thousand refugees: nine of which are in Vojvodina. The refugees make more than ten percent of the local population in 11 out of $45 \mathrm{mu}$ nicipalities in Vojvodina. Crucial factors in selection of destinations are, obviously, ethnic and spatial distance.

Around 92\% of refugees are Serbs and, naturally, they took refuge in ethnically and spatially closest municipalities. However, in an effort to explain extremely large immigrations in Vojvodina, one additional factor should be taken into account: postwar colonization. In the period between 1945-1948 216,306 people were colonized to Vojvodina, which increased current provincial population for $13 \%$ (which is the same as the wave of refugees in 1990-1996). The strongest colonization waves were from Bosnia and Herzegovina and Croatia from which $(136,020$ or $62.9 \%)$. of the total number of colonists) has come. In 1990's almost entire refugee population came from those two republics and they found their first shelter with their cousins, friends, acquaintances, with their "mates" (Djurdjev, 1994). Colonists were settled in homogenous groups and they managed to preserve their cultural customs, as well as relationships with their relatives and friends from home (Djurdjev, 1995). Refugees from Croatia prevail in Vojvodina Province and refugees from Bosnia and Herzegovina in the Central Serbia due to vicinity of the common border.

\section{Ethnic and Religious Structure of Vojvodina}

Vojvodina is one of the most heterogeneous regions in Europe as regards the ethnic and religious background of its population. The present ethnic structure of Vojvodina is the result of numerous historical events that occurred during the last three centuries, for the moment of the liberation from the Turkish occupation is widely considered the beginning of development of recent Vojvodina population. However, during the period, there were significant changes in the ethnic structure of the population, primarily due to wars, new boundaries and migrations caused by various factors. 


\section{Changes in the ethnic structure during the $20^{\text {th }}$ century}

Development of the ethnic structure on the territory of present Vojvodina during the period can be divided into several phases. The first one coincides with the period of the Austro-Hungarian domination until 1918. It is characterized by the growth of the absolute number of almost all ethnic groups, primarily due to the bigger birthrate (11$14 \%$ o). However, the relative growth of Vojvodina ethnic groups was relatively disbalanced. The number of Hungarians increased most dynamically, (which was normal since the process itself sublimated great birthrate, immigration and ethnic assimilation, that is 'hungarisation'). Therefore, the number of Hungarians increased by $66.3 \%$ in southeast Bačka, by $82.3 \%$ in the middle and south Banat, while in Srem it increased by $130 \%$ (Kocsis, 1995). During the period, there was a slight decrease in the number and presence of the Germans. Namely, between 1899 and 1913, the territory of today's Vojvodina, mostly Banat was subject to great emigration. It is thought that more than 150000 people emigrated from the region, mostly to America and other offshore countries. More than half of the emigrants were Germans (53\%), while members of other ethnic communities namely Serbs made $18 \%$, Hungarians $10 \%$ of emigrants. (Kocsis, 1995)

Consequences of the First World War (1914-1918) can be divided into two groups. One would be the consequences caused by the war: physical losses (at the front, in the battle or in the background due to illness) and demographic (negative birthrate), while the other group would be the consequences of the end of the war and change of the government (emigration of some ethnic groups, changes of ethnicity, etc.). If we compare the results from 1910 census and 1921 census (table 7), we can see that the number of all ethnic groups was increasing, but the number of Hungarians and Romanians. The extreme growth was noted with Croats (that is the result of many up-to-then Bunjevci declaring themselves as Croats). The number of Hungarians decreased due to logical reasons; there were massive migrations of state officials and intelligence into the new territory of Hungary. Similar is the explanation for the decrease in the number of Romanians; boundaries of Romania became very close. During the period between the wars, there was a colonization of the population into Vojvodina - on voluntary basis, so the number of Serbs in Vojvodina increased by 48,000 .

The Second World War had slightly graver consequences as regards the ethnic constitution of Vojvodina population. When it comes to the ethnic constitution the importance of war consequences (if we exclude Jews), was significantly overpow- ered by the consequences of migrations. First, Germans moved out or were banned from Vojvodina and Yugoslavia, then their settlements were colonized and taken over by Yugoslavs. Out of 225,696 of colonist 162,447 of them were Serbs, 40,176 people from Montenegro, 12,000 Macedonians, 7,134 Croats, 2,091 Slovenians, etc. (Gaćeša, 1984), although some of them did not stay in Vojvodina but returned to their hometowns. Thus, long-lasting ethnic constitution of Vojvodna was significantly changed, for the Serbs who were relatively speaking dominating ethnicity during the period in question, then became absolutely dominating ethnicity. At the same time, Germans, who had been the third large ethnic community in Vojvodina almost completely, disappeared from the region. There was a significant increase in the Hungarian population, partially due to the convertion of 15,000 of Germans into Hungarians.

During the post-war period, until the mid 60s, the number of all ethnic groups was increasing due to the high birthrate. A bit more dynamic increase was in the number of Serbs and Montenegrins, due to the immigration of their countrymen from other parts of the Former Yugoslavia. However, during the last two decades, there was a significant decrease in the birthrate (leading to the decrease in most ethnic communities in Vojvodina: Hungarians, Croats, Slovaks, Romanians, Ruthenians, etc. During the same period the number of Serbs increased (resulting from immigration and assimilation, while the increase in the number of people from Montenegro and Macedonia resulted from their continuous moving in).

The great ethnic heterogeneousness in Vojvodina resulted in numerous mixed marriages and self-declaration of the significant part of Vojvodina population as Yugoslavs (which was a peculiar way of anti-national declaration). The group became the third large group in Yugoslavia and differently from other parts of Yugoslavia where the number of Yugoslavs drastically decreased at 1991 census, it increased in Vojvodina.

The beginning of the 90 s signified new, different changes in Vojvodina ethnic constitution. Out breaking nationalism in the republics of the Former Yugoslavia led to Yugoslav people moving into their native republics. In Vojvodina, it mostly reflected in Croats moving out and re-declaring themselves as Bunjevci and Sokci that is settling of the Serbs who came from Croatia and Bosnia and Herzegovina. With the outbreak of the war on the territory of the Former Yugoslavia, this processes reached their peak. Large numbers of Serb refugees found shelter in Vojvodina, while at the same time, certain number of members of minorities left the Province. However, their emigration was not always due to political reasons (insecurity, escape from mobilization, etc) but economic too (low standard, international economic sanctions imposed on Federal Republic of Yugoslavia, etc). Therefore, the Serb population also moved out of Vojvodina.

2002 census represents the sublimation of all demographic events caused by the war on the territory of the Former Yugoslavia, primarily migrations of the particular ethnic groups. Within the relatively equal number of the total population, the number of Serbs increased, while, in parallel, the number of all other ethnic groups decreased.

\section{Changes in the religious structure during the $20^{\text {th }}$ century}

Religious structure of Vojvodina population basically coincides with the ethnic one. Until the end of the Second World War the Catholics were the dominant religious community (Croats, most of Hungarians and part of the Germans), and then orthodox (Serbs and Romanians). Protestants were continuously the third large community including (Slovaks, part of the Germans and Hungarians). After the Second World War the Jews almost completely disappeared from Vojvodina, while it was only then that the Moslems appeared in larger numbers.

Out of six censuses in the 20th century, which registered population according to their religious background, most interesting is the one from 1953. It included combined data on ethnic and religious background of the population for the first time, thus offering us many interesting information. Thus, for example, orthodox were mostly Serbs (79.0\%), Romanians $(6.5 \%)$ and people from Montenegro (1.28\%) while among the catholics, Hungarians were most numerous with (69.6\%), then Croats (20.3\%), Protestants mostly consisted of Slovaks (60.8\%) and Hungarians (29.3\%), Ruthenians were mostly Greek catholics (uniates) etc. The analysis of ethnic groups according to their religious affiliation was equally interesting: Serbs were mostly orthodox (79.0\%) and atheists (19.7\%), Croats mostly catholics (88.8\%) and atheists (9.5\%), Slovenians also catholics (70.2\%) and atheists (23.0\%), Macedonians mostly orthodox (72.0\%) and atheists (24.5\%), people from Montenegro mostly atheists $(69.0 \%)$ and orthodox (30.2\%), Yugoslavs mostly catholics (76.6\%), Moslems (10.4\%) and atheists $(9.3 \%)$, Slovaks mostly protestants (87.1\%), catholics (5.8\%) and atheists (3.4\%), Hungarians catholics (89.8\%), protestants $(7.1 \%)$ and atheists $(2.5 \%)$, Romanians mostly orthodox (87.9\%) and atheists (4.5\%) etc. (Kicošev, 1995).

It is interesting that according to the results of 1991 census, at the time of national and religious euphoria, the number 
of persons that did not have any religious beliefs increased. However, as well as in the case of the ethnic situation in Vojvodina, religious homogenization was becoming more and more obvious, which represented only one of the consequences of the latest political and demographic developments in Vojvodina and its surrounding.

\section{The presence of minorities in} the Administration / Bodies of

\section{Authority}

Based on the survey from the end of November, beginning of December 2002, data from 17 Provincial Secretariats (out of 18 in total) and 42 municipalities from the territory of the Autonomous Province of Vojvodina (out of 45 in total) was collected. There are three

municipalities with no reliable data: Alibunar (Serb-Romanian population), Mali Idjos (mostly Hungarians) and Novi Sad (mostly Serbs). Lack of data for the municipality of Novi Sad is a significant shortcoming of the survey due to the fact that 1200 employees that is $1 / 5$ of the total number of employees in the Administration of the Autonomous Province of Vojvodina are from the municipality of Novi Sad. 4581 employees were the subject to the survey. Serbs, Montenegrins, Jews, Ruthenians and Ukranians, who are reserved, regionally distributed or neutral, are more present in the Administration/ Bodies of Authority of the Autonomous Province of Vojvodina than they were in the ethnic structure of the population of Vojvodina in 1991. Compared to the indicator, less present are Yugoslavs, Croats, Bunjevci, Hungarians, Macedonians, Moslems, Germans, Romans, Romanians, Slovaks, Slovenians, Czechs and Šokci. In addition, Bulgarians, Greeks, Albanians, Poles and Russians are proportionately present, compared to their share in the ethnic structure in 1991.

\section{Presence of ethnic groups in the system of education}

In case there were more than 15 applicants for the enrollment in primary school where the lectures would be in the language of their minority, they would be able to exercise the right. However, there is a possibility for the school to organize such classes for less than 15 pupils. For those pupils members of ethnic minorities, who choose to attend classes in Serbian language, an opportunity for learning their native language accompanied with the elements of their national culture would be provided. It would of course be optional, two lessons per week, if pupils, that is their parents show interest in doing so.

Hungarians. During the school year of 1997/98 classes in Hungarian, as regards primary education, were organized in 29 municipalities, 113 educational units that is 83 primary schools and 35 field classes.
Compulsory limit for organizing classes in Hungarian was at least 5 pupils.

Total number of pupils belonging to Hungarian minority in the sector of primary education Were 27.140, out of which 21.496 or $79,2 \%$ had classes in their native language. 5633 Hungarian pupils attended classes in Serbian language (that is $20,8 \%$ of the total).For pupils attending classes in Serbian, classes of Hungarian accompanied with the elements of their national culture were provided, twice a week on voluntary basis. 1732 Hungarian pupils attended these classes (out of 5633) In grammar schools, there were 9502 Hungarian pupils, during the same school year. 6575 or $69,2 \%$ attended classes in their native language.

Hungarians make 9,0\% of the total number of students going for higher education (that is 579). 264 of them attended classes in Serbian while 315 attended classes in their native language. There were Hungarian 1703 students attending university (that is $6,4 \%$ of the total number of students at faculties in Vojvodina). 1292 had lectures in Serbian and only 411 in their native language.

Slovaks. During the school year of 1997/98, there were 12 municipalities, 17 primary schools and 2 field classes with the total of 3.909 pupils divided in 185 classes where regular lessons were held in Slovak. $73.5 \%$ of all Slovak pupils had lessons in their native language, in primary education system. Bilingual lessons, that is in both Serbian and Slovak was organized in two municipalities, that is two primary schools with 115 students divided into 5 classes. 707 students chose to attend lessons of Serbian, optionally while in 11 municipalities and 40 primary schools lessons of Slovak, supplemented with the elements of their national culture were organized twice a week.

During the school year of 1997/98 1861 Slovak students attended grammar schools, out of which only 390 (that is $21,0 \%$ ) attended classes in their native language. Lessons in Slovak were organized in 13 classes of two grammar schools (Bački Petrovac and Kovačica). Lessons of Slovak with the elements of Slovak national culture were attended by 221 Slovak students who attended regular lessons in Serbian, in seven grammar schools. During the school year of 1997/98 there were 92 Slovak student completing their higher education (that is $1,4 \%$ of the total number of students attending higher schools) During the same year, there were 276 Slovak students attending university, which made $1,1 \%$ of the total number of students. 30 of them are attending lectures in their native language at the University of Novi Sad, Faculty of Philosophy, Slovak Language Department. In Bački Petrovac, there is one group of the Faculty for Teachers from Sombor, where human resources for teaching in Slovak are completing their education.

Romanians. Education in Romanian can be completed in nine municipalities, 18 primary schools and 14 field classes with the total of 1606 students divided in 121 classes. There were 2447 of Romanian students attending primary schools, 1564 or $64,0 \%$ out of which were attending lessons in their native language. Optional lessons of Romanian with elements of the Romanian culture for those who were attending lessons in Serbian was organized in seven municipalities, nine primary schools for the total of 183 pupils. 578 Romanian students were attending regular grammar schools, 177 out of which in their native language, that was $30,6 \%$. Education in Romanian can be completed in two municipalities, that is two schools with 8 classes (High School of Economy in Alibunar and Grammar School in Vršac). Students who attend lessons in Serbian can also attend optional lessons of Romanian with the elements of the Romanian culture in one school in Vrsac and one school in Kovacica with the total of 15 students who actually chose to do so.

Romanian students made $0,7 \%$ that is 43 of the total number of students attending Higher schools. Lectures in Romanian were organized at the School of Higher Education for Teachers in Vrsac with the total of 25 students while the remaining $18 \mathrm{stu}$ dents attended lectures in Serbian. 64 Romanian students, that is $0,2 \%$ of the total number of students, attended university. There were 21 student of Romanian at the University of Novi Sad, Faculty of Philosophy, Romanian Language Department, while the others completed their education in Serbian. During the school year of 1998/99 in Vrsac, one section of the Faculty for Teachers in Belgrade was opened for those who would later on teach in Romanian.

Ruthenians. Three municipalities and three primary schools with 748 pupils have lessons in Ruthenian language. Out of 1494 Ruthenian students 733 or 49,18 attended primary educationn in Ruthenian For those who attended lessons in Serbian, there were optional lessons of Ruthenian with the elements of the Rutheanian culture organized twice a week in six municipalities and 24 primary schools for the total of 358 students. 608 Ruthenian students attended grammar schools, where only 70 of them attended lessons in their native language. Classes in Ruthenian were organized in the Grammar School in Ruski Krstur for four classes. There were 38 students attending Higher Schools and 135 Ruthenian students attending university.

Romanies (Gypsies). The large number of Roma pupils attend schools in Serbian, then Hungarian, Slovak, and Ruthenian. Optional lessons in Romany are organized in two schools in Tovarisevo and Obrovac. 
Ukrainians. Five primary schools in municipalities of Vrbas and Kula organized lessons of Ukrainian with the elements of Ukrainian culture for 117 Ukrainian students.

\section{Equal Opportunities for Both Sexes}

The analysis of equal opportunities for both sexes can be made according to the presence of both sexes in the Administration/Bodies of Authority and based on their presence in the education system.

\section{The presence of women in the}

\section{Administration / Bodies of}

\section{Authority}

For the needs of the medium-term-plan of the economic development of the Autonomous Province of Vojvodina, data on the presence of both sexes in the Administration /Bodies of Authority have been collected from 17 Provincial Secretariats (out of 18) and 42 municipalities in Vojvodina (out of 45), reflecting the status at the end of 2002. The data show that women are significantly more present in the Administration: out of 4581 employees, at the end of 2002 , women account for $62,7 \%$. Women's participation with almost $2 / 3$ in the activities which are highly placed in the social hierarchy should be taken with caution. The information does not necessarily reflect the real status nor the presence of women in the internal hierarchy.

\section{The presence of women in the education system}

The data from the current registry book show that the employed women are less present in the education system as the level of the educational institution is getting higher. Thus, women teachers employed in primary schools in the school year of 1999/2000 accounted for $76,2 \%$ (in the Central Serbia it was $68,7 \%$ ), in secondary schools $60,8 \%$ (the Central Serbia $58,2 \%$ ), while at universities it was only $40,8 \%$ (the Central Serbia 37,3\%).

\section{Education}

The two fundamental elements of the population structure according to their education are literacy and qualifications.

According to data from 1991 census, $4,1 \%$ of the population in Vojvodina was illiterate. At the same time, there is a huge disproportion of the illiterate in terms of gender, only $1,9 \%$ of them being men and the remaining $6,2 \%$ women. Similar$l y$, there is a huge difference in the literacy status between the "agricultural" and "non-agricultural" population. In 1991, only $14,3 \%$ of the agricultural population was illiterate (14,9\% men and $13,7 \%$ women), while only $3,5 \%$ of the illiterate were non-agricultural population $(1,5 \%$ men and 5,3\% women). The category of the illiterate population comprises mostly eld- erly population. Based on the same census (1991), 46,6\% of the total number of the illiterate in Vojvodina was older than $65,44,4 \%$ was between $35-64,6,1 \%$ between $20-34$ years, and 2,6\% between 10 19 years of age.

In 1991, the population structure of Vojvodina was as follows: $10,5 \%$ of the population older than 15 had no education whatsoever or only 1-3 grades of the primary education, $23,0 \%$ completed 4 7 grades of the primary education, $25,3 \%$ obtained primary school diploma, 33,0\% had secondary education and $7,4 \%$ higher or university education. Similar to the literacy status, the worst educational structure was that of the agricultural, female and elderly population.

There are 20,2 students per teacher in primary schools, 16,6 in secondary schools while in higher schools and universities there are 17,0 students per lecturer.

\section{Percentage of the youth at} universities and their structure according to gender

If we compare the number of students during the school year of 1999/2000 with the number of younger population (between 0 19 years of age according to 2002 census), we can notice that the percentage of those who study at universities equals $7,2 \%$. However, if we compare the number of students to the age group of those between 20 24 years of age (most corresponding with the age of students) then the percentage amounts to $23,4 \%$. 2000/2001. The given data point to the fact that the share of female gender, in the process of education at higher schools and universities is bigger
(54,4\%), that is secondary schools $(50,9 \%)$ than the male, while the male dominates in the primary education with $(51,4 \%)$.

\section{Success during the education}

Unfortunately, there are no statistical data fro the primary and secondary education grades of the students. At the University of Novi Sad, $53,2 \%$ out of the total number of enrolled students obtain their diplomas. Female students account for $63,4 \%$ of the students with degree.

\section{References}

Acsády I. 1896. Magyarország népessége a Pragmatica Sanctio korában 17201721, Magyar Statisztikai Közlemények XII, Budapest.

Announcement 31, 2002. Final results of census 2002. RepublicBureau of Statistics, Belgrade.

Gaćeša Nikola, 1984. Agrarian reform and coloniasation in Yugoslavia between 1945-1948, Matica srpska, Novi Sad.

International Migration Bulletin, 1996. Economic Commisiom for Europe (ECE), Geneva, vol. 9.

International Statistical Yearbook 2002, 2002. Database producers.

Kicošev Saša, 1995. Changes in the religious structure of the population in Vojvodina during the 20th century. Proceedings of scientific works of the Institute of Geography, No. 25.

Kocsis Károly, 1995. Hungarian Minorities in the Carpathian Basain, Matthias Corvinus Publishing, Toronto-Buffalo.

Popović Dušan, 1952. Serbs in Bačka by the end of 18 th century, SANU, Belgrade.

Swot Analysis Draft of Human Resources of the Regional Development Plan for the Autonomous Province of Vojvodina

\section{STRENGHTS}

- Similar demographic regimes in surrounding - Multicultural

- Short term stimulus of refugees to the demographic development

- Increase in the number of employees in the private sector

- Increase in the number of active women

- Decrease in the share of unemployed women in the total number of the unemployed

\section{OPPORTUNITIES}

- More intensive cooperation of the economic and non-economic organizations and educational institutions as regards the vocational training and specialization. - Granting agricultural loans to refugees in order to facilitate the purchase of deserted estates in Banat and demographic and economic revitalization of the region.

- Implementation of the family planning programme.

\section{WEAKNESSES}

- The process of depopulation. The trend towards the drop in the total population.

- Prevalence of the elderly population.

- The tendency towards further aging of the population.

- Demographic extinction of village settlements.

- Unsolved refugee status of the many lack of specific professions.

- The growth of unemployment.

- The drop in the active population - in terms of work.

- Inequality of women in terms of getting a job and the positions.

- Poverty $-8.8 \%$ of the total population in Vojvodina lives in poverty.

\section{THREATS}

- Outflow of young, highly educated staff. - Unfavorable age structure of employed 
Breznik Dušan, 1991. Population of Yugoslavia. Chronos, Titograd.

Demographic Statistics 1991, 1993. Federal Institute of Statistics, Belgrade.

Djurdjev S. Branislav, 1995. Border Effects on Household Dissolution in the Banat Region,

Yugoslavia. GeoJournal, Vol. 35, No. 4, pp. 409-413.

Djurdjev S. Branislav, 1988. Demographic distortion of the population in Vojvodina. Zbornik Matice srpske for social studies, No. 85, pp. 67-82.

Djurdjev S. Branislav, 1994. Peopling of the Vojvodina Province after the Second World War. The first regional geography conference: "Geographical Researches in the Carpathian-Danube Space", pp. 139-148. Universitatea de Vest din Timişoara, Facultatea de Chimie-Biologie-Geografie, Departamentul de Geografie.

Djurdjev S. Branislav, 1996. Refugee problem in Yugoslavia. Proceedings of Matica srpska for social studies, No. 100, p. 305-319.

Djurdjev S. Branislav, 1986. Progress of external migrations in Vojvodina. Zbornik Matice srpske for social studies, No. 80, p. 109-127.
Djurdjev S. Branislav, Vesna Katić, Dubravka Žarkov, 1992. Prevalence of the Formal Zadruga in the Village of Vilovo, Voivodina, Serbia. Journal of Family History, Vol. 17, No. 3, pp. 319-329.

Djurdjev S. Branislav, Miroljub Rančić, 1995. Population growth. In: Mirjana Rasević (ed.), editor: Progress of population in Serbia between 1950 and 1991, pp. 29-44. Center for Demographic research, Institute of Social studies, Belgrade.

Radovanović Svetlana (Ed.), 1995. Population and households in Yugoslavia according to 1991 census. Federal Institue of Statistics, Center for Demographic research of the Institute for Social Studies,Belgrade.

Ćurčić Slobodan, 1996. Number of inhabitants in Vojvodina. Matica srpska, Novi Sad.

Municipalities in Serbia 2001, 2002. Republics Bureau of Statistics, Belgrade.

Statistical Yearbook of Serbia, 2000. Republics Bureau of Statistics, Belgrade

Statistical Yearbook of Serbia, 2001. Republics Bureau of Statistics, Belgrade

Statistical Yearbook of Yugoslavia 2000, 2001. Federal Institute of Statistics, Belgrade
Statistical Bulletin, 2001. SB 2274, Federal Institute of Statistics, Belgrade.

UNHCR, 1996. Census of Refugees and Other War-Affected Persons in FR Yugoslavia. UNHCR, Commisioner for Refugees of the Republic of Serbia and Commisioner for Refugees of the Republic of Montenegro, Belgrade.

\section{Acknowledgements}

The Regional Development Plan is a joint venture of the Executive Council of the Autonomous Province of Vojvodina and the German Organization for Technical Cooperation.

The Regional Development Plan was made by the Team for Development, independent scientific workers, researches. The complete work was organized according to the teams of experts, working groups for Economy, Infrastructure and Human Resources.

On the German side, theproject washighly contributed by Dr HEINZ SCHRUMPF from the RWI Institute. Žarko Maletin Coordinator for Regional and Local Economic Development of the German Organization for Technical Cooperation, GTZ did his best to successfully organize this work. 